\title{
Gábor Máthé
}

\section{Post-Modern Rule of Law}

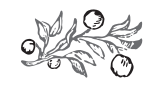

\section{Summary}

In this paper the classical rule of law, born in the 19th century, is compared to the current post-modern rule of law through the opinion of the author and of the relevant international experts. The paper focuses on nation states' sovereignty, the settlement of jurisprudential problems between the European Union and its Member States, the elimination of anomalies in the post-modern rule of law, as an ultimate guarantee, the constitutional courts of nation states and the Conference of European Constitutional Courts.

Keywords: nation state's sovereignty, postmodern rule of law, postmodern rule of law, the constitutional court of nation states, Conference of European Constitutional Courts

\section{Clasidal Rule of State in the 19th Century}

Balance in the first half of the past two hundred years was based on the principles of military alliance, settled territorial arrangements and cooperation between the three founders of the Holy Alliance: Tsar Alexander I of Russia, Emperor of Austria and King of Hungary Francis I, and King Frederick William III of Prussia. In the history of Europe the initiatives taken by great powers were accompanied by illustrious congresses. Among them, of paramount significance was the 19th-century Congress of Vienna, as it successfully managed international crises up to 1914 (Harmat, 2015). The simultaneous enforcement of the three requirements was the token of the continent's success. Legitimacy, or in other words, the exercise of power through inheritance or elections, and then the alliance of stated in equilibrium was the criterion, and ulti-

Dr. Gábor Máthé professor emeritus at National University of Public Service and Eötvös Loránd University (mathe.gabor@uni-nke.hu). 
mately, responsibility for the future always predominated in conflict resolution. In the first one hundred years after the congress, a new order evolved. Legitimacy was proclaimed in opposition to the ideas of the French Revolution, and primarily monarchic and dynastic solidarity were manifest in this restoration going against the revolution. Moreover, this power was Christian: it was built in an alliance between the throne and the altar, and could finally remain continental (Máthé, 2015a).

However, once it was realised that the interests had changed, by the 1860's the alliance began to gradually incorporate the power policy principles built on fundamentally new ideas, and first and foremost it recognised the need to create the rule of law.

The two basic pillars of the rule of law is freedom and the sacredness of property: and in the triad of state, society and the individual person, it is an essential requirement that institutions are established to control the exercise of power. The early concept of the rule of law was a summary of the desires cherished by political liberalism: the ruler's subjection to positive law, the submission of state activity to law, and the prevention of using the formal opportunities inherent in legislation and execution for unlawful intervention in citizens' fundamental rights.

In the state that evolved, a compromise was made to the benefit of a formal state. According to the Viennese professor Ogris, the nature of the rule of law secures the integrity of law and order and not its content. The essence of the state is that through law it determines and unalterably ensures the trajectory and limits of its own operation, and the breathing room for its citizens. As he put it, directly, in its capacity as a state, the state should not reach beyond the scope of law in implementing moral ideas. It became clear that the retention of the elbowroom for certain legal titles, legal protection and judges has a stabilising and financially beneficial effect. Thus, politicians' interest became focussed on the results to be achieved, and formal legal protection became a central issue especially in the field of state administrative affairs. In Werner Ogris's witty wording: The idea of the rule of law drifted apart from the theory of the state and vigorously jumped over to administrative law and the academic discipline of public administration (Ogris, 2010, p. 23). This is because the crucial question was the enforcement of rights in practice. In response to this the compulsion of control over public administration was born, aptly expressed in Otto Mayer's opinion that the rule of law is the state of a wellorganised public administrative law. Consequently, in 1896, the priority institution of legal protection, the Administrative Court, was also established in Hungary, and thus the citizens' protection against the unlawful measures taken by the state was manifest in a specific form. This was subsequently completed by other corner-stones like the division of power, the independence of judges and the system of fundamental rights, in place for several generations now. Submission of the classical power triad to law was ensured by great legislations: in addition to our commercial act, proposals that represented outstanding achievements in the codification of private law, the code of civil procedure, and the masterpiece of criminal law, the criminal code named Csemegi Code after its maker, which served several generations of lawyers in dealing with the facts.

The dual monarchy that evolved in Eastern and Central Europe in the 19th century comprised two independent countries: Austria and Hungary. They had com- 
mon affairs and joint organisations to handle them. As a multi-cultural entity that had an incredible geographical diversity, the Monarchy put the principles of the Holy Alliance into practice, successfully established the full range of the institutions required for the division of power and created the codes carrying European legal values (Sári, 1995; Máthé, 2015b). In a characterisation of the Monarchy, it is important to highlight that the system of law had priority and the economy unfolded within this framework. Basically due to its social motivation, between 1870 and 1914 the economy operating with the predominance of local markets resulted in a new, bourgeois lifestyle. The economy of the dualist Monarchy may be a notable example, as the budgetary ratio of pragmatic affairs was 70:30, and after a few changes, for the last time in 1908 it reached 63.6 to 36.4 to the detriment of the countries under the imperial council (Balogh, 2007). Consequently, the Hungarian sovereign benefited from economic efficiency. In the assessment of Eisenmann, a French historian, with the 1867 Compromise, Hungary was granted half of all the rights for a third of the costs, and obtained two-thirds of the influence in the Monarchy (Eisenmann, 1904).

Fredric Jameson, a significant contemporary US thinker, provided a highly pertinent assessment of the Monarchy in a postmodern cultural frame of mind. Among others, this is important because in our time theories are only created about the conditions of opportunities in our period, and they merely include lists of changes and transformations. Jameson endeavours to change by thinking of something in a historical perspective in an age when the method of understanding the present from the past has already been forgotten. "...the Austro-Hungarian Empire was in any way a nightmare. On the contrary, besides being the last of the old archaic empires, it was also the first multinational and multi-ethnic state: comfortably inefficient when compared with Prussia, humane and tolerant when juxtaposed with the czars; finally not a bad arrangement at all, and an intriguing model in our own postnational period, still riven by nationalisms" (Jameson, 1991, p. 316).

\section{THE POSTMODERN RULE OF LAW IN OUR DAYS}

The procedure of implementing the basic principles of the rule of law has never been seamless: either in the period of establishment or today. It is important to note that the rule-of-law model is far from being a closed system, and as such it needs to be constantly developed. Nothing guarantees that its achievements will last forever. This is well illustrated by the European Union in the 21st century. This is because the Member States struggle helplessly in the grip of the common and the individual systems of political institutions, as the situation has been characterised by the former President of the European Parliament, adding that in Europe, sovereignty is based on the separation of powers: we have a government Parliament can decide against, and an independent judiciary that controls compliance with the law.

At the beginning of the 20th century the Treaty of Versailles that closed World War I, upset the territorial order and destabilized Central Europe. After World War III, with the Yalta Conference and the subsequent Treaty f Paris, Europe set out on 
the way to becoming Transatlantic and gradually losing its global political influence. Then the Treaty of Malta, signed on 2 December 1989, reintegrated Central and Eastern Europe and represented a completely new standard of quality, as these areas were required to return to the political and economic relations laid down in the 20th-century Roman Treaties in the spirit of the Washington Consensus, mediated by the USA.

In a world that had become unipolar, the integration of Central and Eastern Europe departed even more from the previous established principles. The order of elements included in the Washington Consensus, namely, privatisation, deregulation and commercial liberalisation, was implemented on the basis of the scenario created by the international finance. The reason was that the creators of the programme failed to distinguish the various dimensions of statehood and the ways they relate to economic development. Privatisation resulted in enormous asymmetries and the state was supposed to correct them. Milton Friedman, the most excellent representative of free-market economics, aptly noted that the tenet has been proven: legal order is probably more essential than privatisation (Gecsényi and Máthé, 2009, pp. 16-18).

The correlations between these international processes are described by academician and professor of economics, Dr. Béla Kádár in a highly edifying assessment. His clear establishment of the facts is self-explanatory: "The international climate in which Europe's destiny was shaped by powers outside Europe for half a century evolved in the wake of two self-destructive world wars of the 20th century (and Europe's civil war): in Yalta, according to Soviet, and in Malta, in December 1989, according to American interests. The conditions and duties of the change of regime were determined from outside. This was a fundamental factor that shaped the elbowroom,... however, in this conceptual determination, closing the gap by granting financial support to the countries of Central Europe was not a strategic goal."

Although in the 1990's "the IMF was given the control panel to set the latitude in the economic transformation of the former socialist countries,... however, the IMF considered the content of the Washington Congress as a strategy," emphasised the doyen of Hungarian economics, whose professional stance is undisputed. To put it in another way: "In the absence of external financial support, the IMF therapy was merely a conceptual economic policy limitation of movement" (Kádár, 2018).

In his monography, Jameson gives a highly convincing diagnosis of the current theory of postmodernism: "...one may also wonder, with Adorno, whether 'in our time the commodity has not become its own ideology - that is to say, whether practices have not replaced rationcination (or rationalisation), and in particular whether the practice of consumption has not replaced the resolute taking of a stand and the full-throated endorsement of a political opinion. Here too, then, the media meets the market and joins hands upon the body of an older kind of intellectual culture" (Jameson, 1991, p. 406). A similarly true dramatic assessment claims that "even the nation-state itself has ceased to play a central functional and formal role in a process that has in a new quantum leap of capital prodigiously expanded beyond them, leaving them behind as ruined and archaic remains of earlier stages in the development of this mode of production" (Jameson, 1991, p. 420). 
According to an opinion that has become a firm conviction; the most significant international gap in development is that the compromise cooperation between the developed North and the feebly developed South, comprising the largest part of the world's population, has become unviable. In the globalising world, the asymmetric interdependences between capital exporter and capital importer countries appear to be additional principles. The narrowing of national sovereignty over Hungarian economy, in other words, giving the decisions determining the future structure of the economy into foreign hands leads to the expansion of transnational companies, which implement a global business policy through their strategic cooperation and the transfer of goods, capital and technologies. This globalisation has a harmful effect, as it erodes national sovereignty, and more specifically, state sovereignty, weakens the government's offset of the market preponderance. Thus globalisation re-defines the role of the nation-state as the efficient manager of the national economy (Szentes, 2002).

It should also be admitted that in the age of globalisation it is the governments' accountability rather than the role of the state that decreases. To a major extent, the success of efforts at making the highest possible profit at the lowest cost and without risks in the framework of cooperation with transnational companies depends on a government's policy. However, national economies should still make efforts at ensuring that mutually supportive impacts predominate national development.

\section{CONSEQUENCES OF CHANGES IN THE SPATIAL STRUCTURE}

In the 1990's, a new concept emerged in social sciences: the supraterritorial space. As a new phenomenon, it indicated that something new had evolved in contrast to the traditional territorial structures of states. The relationship between the economy and law was predominated by the contemporary contractual system of international law, which, however, fit to the classic spatial structure, according to a diagnosis by József Hargitai, a specialist of the history of diplomacy. After World War I, modern international law did not represent a change in the traditional spatial structure of law, moreover, the internal development of international law, or if you please, its becoming international and expansion beyond European culture, did not trigger changes in the spatial structure (Hargitai, 2004).

If a state is not submitted to the legal rule of another state, it is sovereign. However, international law is not include any obligation to maintain sovereignty, thus a state may even waive part or whole of its sovereignty, say by joining a federation. "Argumento a maiore ad minus it follows from this that it is allowed to waive the partial elements of sovereignty, and this process actually takes place whenever a contract is concluded to the point where the concept of sovereignty, for example, by accession to the $\mathrm{EU}$, is rendered nearly meaningless" (Hargitai, 2004).

The picture that had evolved by the early 21st century may be summed up as follows: in the system of international law and the universal treaties appearing in it, the state has been caught in the net of obligations that have upset the freedom of international law from values. The expansion of the modern-age tenet that law can also 
arise from alternative sources other than legislation is no accident. This law provides a framework for the world market structure, and broadly detaches itself nation-state or international legislations (Hargitai, 2008). The supporters of the new world order, or the postmodern world, proactively urge these processes, and while states are losing their previous political, legal and economic powers, other participants, acting in parallel and against the state, simultaneously increase their influence. In addition, multinational companies, civil society organisations, initiatives and NGOs also gain enormous influence, and using the globally enforced standards, they generate a peculiar "earthquake". As an example of the application of the so-called transnational law, MC's cross-border organisational structures need to be highlighted, let alone the syndrome characterised by the saying "the world is a global assembly line" with the flow of goods operated between the various branches and subsidiaries of international companies rather than export and import run by nation-states. In addition, as a peculiar development, they only obey regulations aimed at maximising profit within their concerns. In addition, they typically do not operate according to the law of the place of investment. A clear explanation may be given for this distinct emancipation through the fact that these companies realise revenues multiple of nation-state budgets.

The 20th century had an endless supply of modalities in "spatial changes". As an example, remember that in the second half of the last century, the aether was still subject to regional rights, however, today multinational telecommunication companies operate according to different rules. The globalised version of this traditional space is manifest as a virtual space (Internet). This is because the Internet has ruined the legal forms of spatial structure. The cyber space or virtual space is nothing more than the set of transactions, relations and ideas created between people and machinery in a communication net. It turned out that the worldwide web was also a scene for economic activities, and functions as a symbolic market, with the flow of real-life goods and capital. However, the state also discovered the Internet, and wants to use increasingly for the modernisation of public administration. The spread of information technology also had a special impact: a professional élite has evolved that takes action with increasing awareness against governments' restrictive legislation. Making reference primarily to the requirements of human rights, this team is technically wellversed enough in programming to override areas already regulated by law.

In order to conclude this outline description of the postmodern rule of law, an interesting feature is recalled. It is thought-provoking that the traditional forms of justice within the frames of nation-states have failed to prove suitable for the effective enforcement of the legal matters of transnational formations. Thus the enhancement of the role of international arbitration tribunals is no accident. It is conspicuous, however, that among the objectives of multinational empires having the power to organise, the "termination" of the state is not yet on the agenda. For the time being, it seems to be sufficient to change the role of the state according to their interests, after all, they need someone to implement the arbitration awards.

To sum up the above, it can be established that the legislative procedures and structures regulated on the basis of traditional nation-state constitutions (the hier- 
archy of legal sources and the legal system) are gradually falling apart. This allows the conclusion drawn at the end of a succinct and highly expressive study by Preuss (1999): The disempowering of state legislators has been implemented. Well, the deprivation of government legislators of their power reached a peak by the establishment of the European Union through the gradual expansion of the EEC. The EU came into existence by transfer of certain elements of the Member States' sovereignty and based on European values. Actually, sovereignty was the greatest achievement of the European civilisation, and the only framework for a viable democracy, claims Thierry Baudet with aphoristic wisdom. Due to volume constraints, the theoretical questions of the "division of power" between states cannot be discussed here, however, it is recommended by all means that sovereignty and the rule of law are complementary concepts (Máthé, 2014).

\section{RETURN TO THE POSITIVISATION OF LAW?}

In his monography, Professor Helmut Coing highlights general legal positivism. He finds that "...in our age, law is the product of an evolution that from archaic social system to ancient high cultures and finally to the modern-day high cultures of our current social forms. This evolution is primarily manifest in control over the ever increasing complexity. Although law is, on the one hand, supposed to provide security for the prevalent regulatory expectation, on the other, it should leave room for the development of new structures of expectation and thus the evolution of further systems of rules" (Coing, 1996, pp. 87-88). In his opinion of the parallel between the normative and cognitive propositions, speaking of the current legal philosophy discourse, he specifically gives a criticism of Luhmann's (1981) theory. The essence of Luhmann's concept is that although positive law comes into existence and is enforced through decisions, a static world order has no role in its legitimation, in contrast to the foundations laid in the European tradition of classical natural law (Strauss, 1999). Positive law should especially be legitimised by the rules of its creation, the political procedure of the decisions adopted to select such rules. Classical natural law was the reflection of an eternal world order, and the idea of a classical justice presumed an overall perfect order of things that could legitimate law and provided criteria for the distinction between just and unjust, or lawful and unlawful, when legal decisions were made. However, by now it has become clear that under the conditions of our complex modern society, this is ruled out. To ensure "an adequate complexity of law", a "system theoretical interpretation" is required to replace it (Coing, 1996).

In the postmodern world of the 21st century, due, among others, to the above, adherence to the requirements of the rule of law is even more indispensable. The rule of law is an undoubtedly one of the fundamental values with legal security as its guiding principle and law used as a factor of gauging the state. Thus today the rule of law is: a constitutional state that regulates the procedure of legislation; a state regulated by laws that set limits to individual behaviour, establish government institutions and determine their structure and competence; and a state that protects law with the help 
of appropriate institutions that enforce compliance with the laws. Its characteristics also include: submission of the legislator to a constitution; the subjection of judicial power to law; the protection of fundamental rights; the accountability of state organisations for compliance with the statutes; the wording of legal orders and the clarity of promulgations.

In his monography published in 2018, Canadian professor Jordan B. Peterson gives an ingenious characterisation of our age: "The insane and incomprehensible postmodern insistence that [...] Society must be altered, or bias eliminated, until all outcomes are equitable. [...] The fact that both of these cannot logically be true, simultaneously, is just ignored (or rationalized away with another appalling post-modern claim: that logic itself - along with the techniques of science - is merely part of an oppressive patriarchal system)" (Peterson, 2018, p. 314). People need principles or otherwise chaos pops its ugly head up. Rules, checks and values. "You must determine where you are going, so that you can bargain for yourself, so that you don't end up resentful... [...] Don't underestimate the power of vision and direction. Define who you are" (Peterson, 2018, p. 63). This instruction also made it clear that we must return to the starting point of natural law and to the positivisation of law.

The reason is that every historical work exists in a one-off form. Law is part of culture, it is bound to objects and primarily provides solutions for problems arising an a social order. Incontestably, economic power and all other kinds of power have a role (or attempt at having a role) in the generation of law. However, the "threads" of culture are strong, and do not tolerate unilateral settlement (Coing, 1996, pp. 163-164). For all these reasons, jurisprudence and its practitioners should have a pivotal role in the solution of the problems causing tension in the EU. Jurisprudence belongs to the humanities. On the one hand, it serves the practical implementation of the system of law, and on the other, it is the discipline of the structures in force. As Edmund Burke has put it in his eloquent assessment: "And first of all, the science of jurisprudence, the pride of the human intellect, which, with all its defects, redundancies, and errors, is the collected reason of ages, combining the principles of original justice with the infinite variety of human concerns..." (Coing, 1996, p. 273).

Controversies in legal literature also characterise our age. As an example of debates on sovereignty, the concept of American researcher Jeremy Rabkin (2004) is highlighted, who agues that the global order must also be based on the sovereignty of states (Máthé, 2013, pp. 160-161). The reason is that these are the unique international factors that unify democratic legitimation through the enforcement capability of statutes. Let alone that, on the basis of unanimous intent, economic areas and regional centres may be established between the individual sovereigns, for instance, in the EU, on areas created by mutual will, within or beyond the borders.

Thus the above may well be the 21 st-century priorities in the theory of the state, providing focus for the transformation of the entire organisation and decision-making mechanism of the European Union, based on the common currency and intended to be operated by the core Member States, not in adjustment to globalisation, but to "several world-economies operating at the same time", as Fernand Braudel (2008) 
aptly put it. Within Europe, various regions of shared value may be established. This is because the peculiarities of historical regions coincide with the current economic trends seen in the EU (Szúcs, 1983).

\section{The changing role of the Constitutional Court}

The peculiar challenges of a comparison of the European legal system are of paramount significance in both legal and political terms, writes Armin von von Bogdandy, Director of the Max Planck Institute of Heidelberg in the sixth volume of his highstandard Handbuch Ius Publicum Europaeum, about constitutional justice. The reason for this special attention is that uniquely in the public law of the European Union, the primary law of the Union, the European Convention on Human Rights and the national laws are interconnected. European public law reconciles this with systems that identify as being based on constitutional rules without blending it into a single legal system. Giving an analysis of the role and practice of constitutional courts and through the conclusions drawn from them, the authors of the volume make it clear that this institution may be the ultimate guarantee for the elimination of the anomalies in the postmodern rule of law (Bogdandy et al., 2016, VII.).

The basis of the European legal system is the area, defined by the laws of the EU Member States, where the regulations of both the Member States and the EU are enforced. This confirms professor Bogdandy's proposition that a complex legal system without a sophisticated set of doctrines usually lacks clarity, predictability and honesty (Máthé, 2017). And when the drafters of the Treaty of the European Union speak of an "area", they mean the full spectrum of interpretations of positive law.

It can be ascertained that constitutional justice is the theoretical basis of comparison within the European legal system, and this role is the pillar of association between constitutional courts. Instead of an interpretation of a clearly designated legal area, the current practice of constitutional courts is far more a kind of "inbuilt" legislative procedure specially focussed on interrelationships. As a result, Bogdandy and his coauthors distinguish five special functions for the constitutional courts operating in the association: interconnection and implementation; translation; legitimation; closing gaps in legal protection and interfacing the law of the European Union and constitutional law. Special significance is attached to closing gaps in legal protection, and more specifically, the role in identity control and in ultra vires control, undertaken to protect the system against the EU's organisations exceeding their authorities. This control is pivotal because it deepens and streamlines the elaboration of common European solutions. The Association of Constitutional Courts also contributes greatly to the development of the European legal system by controlling the activities of the Court of Justice of the European Union and the European Court of Human Rights in horizontal cooperation with the courts of the Member States. For this reason, in resolving the problems in the current jurisprudence it can be considered as a forwardlooking axiom that European culture and European public law may not be rooted solely in the law of the European Union and in the settled case-law of the European 
Court of Human Rights. This rather requires the creation of a network of the national organisations of jurisdiction (Bogdandy et al., 2016, pp. 8-10).

The authors of the book decline the concept of a standard model for the constitutional courts of the European states, and any effort made at it, and giving an analysis of the test of the Treaty of the European Union, they provide evidence that the equivalence of the Member States' constitutional systems implies the recognition of "diverse mechanisms" that protect the rules-based nature of the constitution (Bogdandy et al., 2016, pp. 13-16). Areference is rightly made to the charter of the Conference of European Constitutional Courts, which assigns the judicial review of constitutionality, judicial independence, the basic principles of the democratic rule of law and the protection of human rights into the competence of the court (Bogdandy et al., 2016, pp. 16-17). Regarding the future of this sui generis formation, the excellent experts refer to the quality of argumentation about doctrines in jurisprudence as to a mandatory parable. They find that as a legal guidance, the basic rules-based structure of European public law expects all the stakeholders of the legal system to operate along common knowledge, abilities and values despite the fact that they do not form a homogeneous legal culture. In legal practice and in the theory of law, national interpretations and the content of their doctrines should be examined from the perspective of public law, but there is no need to always endeavour for harmonisation, as there is no general consensus in the jurisprudential and practical local value of the legal acts and configurations included in legal systems In our opinion, the function of comparing constitutional jurisdiction can be classified into the following three types: the verification of a statement; the setting up of a conceptual framework implying a certain statement; and contraposition. As in a pluralistic structure, shared responsibility can only be enforced in the form of a dialogue, a comparative assessment may exist as the building block for the unfolding of common rules-based legislation (Bogdandy et al., 2016, pp. 18-20). This method may, in turn, especially justify the resolution of the legal conflict between the common organisations of the EU and the nation-states as the system of the association of constitutional courts reaches its full potential.

\section{Closing ThOUghts}

The intellectual challenge makes it clear for all of us that legal decisions need to be adopted in professional issues as soon as possible. Let us recall once again the wise ideas of Jordan B. Peterson, as the professor's recommendations bear close consideration: "We must make decisions, here and now, even though the best means and the best goals can never be discerned with certainty. [...] Some reliance on tradition can help us establish our aims. It is reasonable to do what other people have always done, unless we have a very good reason not to. [...] To tell the truth is to bring the most habitable reality into Being. [...] Truth [...] makes nations wealthy and safe. [...] Truth makes the past truly past... [...] Apprehend your personal truth. Communicate it carefully, in an articulate manner, to yourself and others. [...] This will ensure the benevolence of the future, diverging as it might from the certainties of the past" (Peterson, 2018, pp. 221-230). 


\section{Gábor Máthé: Post-Modern Rule of Law}

\section{REFERENCES}

Balogh, J. (2007): Közös érdekú ügyek a dualizmus rendszerében [Affairs in common interest in the system of dualism]. Jogtörténeti Szemle, Vol. 9, No. 3, pp. 2-7.

Bogdandy, A. von; Grabenwarter, C. and Huber, P. M. (Hrsg.) (2016): Handbuch Ius Publicum Europaeum VI. Verfassungsgerichtsbarkeit in Europa: Institutionen. C. F. Müller, Heidelberg.

Braudel, F. (2008): La dynamique du capitalisme. Flammarion, Paris.

Coing, H. (1996): A jogfilozófia alapjai [Outlines of legal philosophy]. Osiris Kiadó, Budapest.

Eisenmann, L. (1904): Le compromis Austro-Hongrois de 1867. Étude sur le dualisme. Paris.

Gecsényi, L. and Máthé, G. (eds.) (2009): Sub clausula 1989. Dokumentumok a politikai rendszerváltozás történetéhez [Contributions to the history of the political change of regime] A Grand Strategy. Magyar Közlöny Lap- és Könyvkiadó, Budapest.

Hargitai, J. (2004): A jog térszerkezetének változásai [Changes in the spatial structure of law]. Manuscript, Budapest.

Hargitai, J. (2008): Nemzetközi jog a gyakorlatban [International law in practice]. Magyar Közlöny Lap- és Könyvkiadó Vállalat, Budapest.

Harmat, Á. P. (2015): A bécsi kongresszus és a Szent Szövetség [The Congress of Vienna and the Holy Alliance]. Történelem Cikkek, http://tortenelemcikkek.hu/node/319.

Jameson, F. (1991): Postmodernism, or The Cultural Logic of Late Capitalism. Duke University Press, Durham.

Kádár, B. (2018): Gazdasági mozgásterünk [Our economic elbowroom]. Manuscript, Budapest.

Király, M. (2007): Egység és sokféleség. Az Európai Unió jogának hatása a kultúrára [Unity and diversity. The impact of the law of the European Union on culture]. Új Ember Kiadó, Budapest.

Luhmann, N. (1981): Gerechtigkeit in den Rechtssystemen der modernen Gesellschaft. In: Luhmann, N. (Hrsg.): Ausdifferenzieung des Rechts. Beitrage zur Rechtssoziologie und Rechtstheorie. Suhrkamp, Frankfurt.

Máthé, G. (2013): Magyary Zoltán tudománytörténeti jelentôsége [The significance of Zoltán Magyari in the history of law]. Polgári Szemle, Vol. 9, No. 3-6.

Máthé, G. (2014): Sovereignty - Constitutional State. Acta Univ. Sapientiae, Legal Studies, Vol. 3, No. 1, pp. 29-40.

Máthé, G. (2015a): A jogállami intézményrendszer klasszikus korszaka és a kettôs monarchia [The classic period of the rule of law institutions and the dual monarchy]. Jogtörténeti Szemle, Vol. 17, No. 3, Special issue, pp. 34-39.

Máthé, G. (2015b): Der ungarische Rechtsstaat in der Zeit der Doppelmonarchie. In: Máthé, G. and Ogris, W. (Hrsg.): Kroatisch-ungarische öffentlich-rechtliche Verhältnisse zur Zeit der Doppelmonarchie. ELTE Eötvös Kiadó, Budapest.

Máthé, G. (2017): Die Entwicklung der Verfassung und des Rechts in Ungarn. Dialóg Campus Kiadó, Budapest.

Ogris, W. (2010): Der Rechtsstaat - eine Einführung. In: Máthé, G. and Ogris, W. (Hrsg.): Die Habsburgermonarchie auf dem Wege zum Rechtsstat? Magyar Közlöny Lap- és Könyvkiadó, Budapest-Wien.

Peterson, J. B. (2018): 12 Rules for Life. An Antidote to Chaos. Random House Canada, Toronto.

Preuss, U. K. (1999): Krise des regulativen Rechts. Kritische Justiz, Vol. 32, No. 1, pp. 126-131.

Rabkin, J. A. (2004): The Case for Sovereignty. Why the World Should Welcome American Independence. American Enterprise Institute, Washington.

Sári, J. (1995): A hatalommegosztás [The division of power]. Osiris Kiadó, Budapest.

Strauss, L. (1953): Natural Rights and History. The University of Chicago Press, Chicago.

Szentes, T. (2002): Globalizáció, regionális integrációk és nemzeti fejlódés korunk világgazdaságában [Globalisation, regional integrations and national development in today's world economy]. Savaria University Press, Szombathely.

Szúcs, J. (1983): Vázlat Európa három történeti régiójáról [A sketch of Europe's three historical regions]. Magvetố Könyvkiadó, Budapest. 